\title{
Diagnosa Penyakit Ginjal Kronis Menggunakan Metode Klasifikasi Naïve Bayes
}

\author{
Harmayani*, Lamhot Sitorus \\ Fakultas Teknik, Prodi Teknik Informatika, Universitas Asahan, Kisaran, Indonesia \\ Program Studi Teknik Informatika, Fakultas ilmu Komputer, Universitas Katolik Santo Thomas, Medan, Indonesia \\ Email 1,"baakamik@yahoo.co.id, ${ }^{2}$ lamhot68@yahoo.com \\ Email Penulis Korespondensi: baakamik@yahoo.co.id
}

\begin{abstract}
Abstrak-Penyakit ginjal Kronis merupakan salah satu penyakit yang sangat berbahaya yang sering sekali tidak dianggap dengan serius akan dampak dari penyakit ini yaitu berujung dengan kematian. Lebih dari 26 juta masyarakat di Amerika Serikat tidak menyadari akan penyakit ginjalnya hanya $8 \%$ yang mulai menyadari penyakit tersebut, setiap tubuh harus diketahui sedari dini baik atau tidak keadaan tubuh// tersebut dengan cara mendiagosanya, pada penelitian ini akan dilakkan klasifiaksi terhadap atribut data diagnose penyakit ginjal kronis bertujuan agar mempermudah proses pengklasifikasian gejala dan pengambilan keputusan terhadap diagnosa penyakit ginjal, proses ini dilakukan dengan menggunakan pendekatan data mining klasifikasi dengan menggunaka metode Naïve Bayes Classifier.
\end{abstract}

Kata Kunci: Penyakit Ginjal Kronis, Data Mining Klasifikasi, Metode Naïve Bayes Classifier

Abstract-Chronic Kidney Disease is a very dangerous disease that is often not seriously considered with the effects of this disease which leads to death. More than 26 million people in the United States are not aware of their kidney disease, only 8\% of them begin to realize the disease, each body must be known early whether or not the body condition / / by diagnosing it, in this study classifications will be carried out on the diagnostic data attributes Chronic kidney disease aims to simplify the process of classifying symptoms and making decisions on the diagnosis of kidney disease, this process is carried out using a data mining classification approach using the Naïve Bayes Classifier method.

Keywords: Chronic Kidney Disease, Data Mining Classification, Naïve Bayes Classifier Method

\section{PENDAHULUAN}

Indonesia merupakan negara yang menekankan masyarakatnya untuk memiliki kehidupan yang sehat dan bersih, karena kesehatan itu sendiri merupakan harta yang paling berharga yang dimiliki masing-masing individu, adanya tubuh yang sehat akan membantu setiap individu menghasilkan banyak kegiatan-kegiatan yang bermakna. Ada sangat banyak masyarakat disekitar kita yang tidak biasa merasakan kehidupan yang normal dikarenakan sebuah penyakit, ada banyak jenis penyakit di dunia ini yang membuat mereka tidak bias bekerja aktif bahkan harus menghentikan impian yang ingin dicapainya dikarenakan kondisi tubuh yang tidak memadai[1].

Ada banyak jenis penyakit yang membuat seseorang harus meninggalkan segala impiannya seperti penyakit Jantung, Gagal Ginjal, Kanker, Tumor Ganas, Leukimia, Kanker Tulang, Kista, TBC dan banyak lainnya, penyakit itu sendiri paling banyak terbentuk akibat pola hidup manusia itu sendiri, salah dalam memilih kebiasaan dan gaya hidup mengakibatkan sering terjadinya kerusakan-kerusakan kecil pada tubuh yang berkelanjutan akan menjadi kerusakan besar yang dapat memperparah kesehatan tubuh dan selanjutnya berujung pada kematian[2].

Apapun jenis penyakitnya pasti akan ditemui oleh setiap individu terutama ketika seseorang usianya semakin beranjak tua, dan imun tubuh akan dengan sendirinya melemah yang membuat banyak penyakit akan mudah menyerang. Tetapi banyak jenis penyakit yang tidak memandang bulu terhadap siapa yang akan terkena penyakit, baik itu penyakit biasa saja seperti Demam, Flu, Batuk dan Diare, hal tersebut merupakan cara tubuh menyampaikan ada yang salah pada tubuh kita, jika sudah membaik maka gejalanya akan hilang lain hal nya dengan penyakit dalam yang dapat merenggut seluruh hal yang ada dihidup seseorang seperti penyakit pada Ginjal[3].

Ginjal merupakan salah satu dari organ vital dalam tubuh manusia dan memiliki dau ginjal didalam tubuh, fungsi ginjal pada tubuh sangatlah banyak seperti menyaring darah yang akan disebarkan keseluruh tubuh, membuang hal yang tidak berguna seperti limbah dan racun dari darah yang ada pada tubuh manusia, membantu mengeluarkan urin memancing hormon yang berfungsi membentuk sel darah merah dan banyak lainnya, ginjal dapat rusak dan tidak berkerja seperti pada umumnya banyak dikarenakan pola hidup yang sangat berantakan seperti minum alkohol, merokok, selalu bergadang, kurangnya asupan air putih, terlalu sering minum soda, makan makanan yang tidak sehat seperti saos, makanaan instan dengan pengawet yang tinggi, tidak pernah berolah raga dan banyak lainnya yang dapat mengakibatkan penyaki terhadap ginjal dan membuat ginjal kehilangan kinerja kerjanya yang biasa disebut dengan Ginjal Kronis atau gagal ginjal[4].

Ginjal Kronis yang biasanya disebut sebagai penyakit gagal ginjal kronis adalah sebuah penyakit yang menunjukan bahwasannya kerja ginjal sudah menurun secara bertahap, jika sudah semakin menurun dan ada pada tahap kerusakan parah maka akan banyak kerusakan yang perlahan-lahan menggerogoti kinerja organ tubuh lainnya, biasanya penyakit ginjal merupakan penyakit yang sangat jarang disadari oleh banyak kalangan masyarakat dikarenakan gejalanya jarang muncul, dan akan sering muncul ketika sudah pada tahap stadium 3 dimana tingkat penurunan biasanya akan menampilkan gejala seperti sesak nafas, sulit tidur, mudah kelelahan, mual-mual dan lainnya. penanganannya adalah orang yang terkena penyakit tersebut harus melakukan 
transplantasi ginjal atau melakukan cuci darah, dan membutuhkan biaya yang sangat banyak dan mahal karena mencegah lebih baik dari pada mengobati[5].

Untuk mencegah penyakit ginjal kronis harus dilakukan deteksi dini pada diri sendir karena penyakit ginjal sangat sering tidak terdeteksi, Lebih dari 26 juta masyarakat di Amerika Serikat tidak menyadari akan penyakit ginjalnya hanya $8 \%$ yang mulai menyadari penyakit tersebut begitu juga dengan masyarakat di Indonesia. Diagnos dini dianggap langkah yang paling tepat untuk mendapatkan keputusan terhadap penyakit ginjal, untuk mendiagnosa penyakit ginjal kronis diperukan klasifikasi terhadap kriteria-kriteria yang menunjukan indikasi terkena penyakit ginjal kroni.

Sangat banyak penelitian sebelumnya tentang penyakit ginjal kronis yang telah diteliti dan dikembangkan dari masa ke masa, penelitian sebelumnya juga sangat banyak mengembangkan sistem untuk menemukan alat untuk mendiagnosa secara pasti dengan menggunakan bantuan teknologi dan komputer, dikembangkan penelitian terhadap penyakit lainnya dengan menggunakan perbandingan antara dua atau tiga metode untuk melihat akurasi suatu metode mulai dari metode C4.5, metode C5.0, metode Naïve Bayes dan lainnya[6].

Pada penelitian ini peneliti menggunakan metode Naïve Bayes karena Naïve Bayes Merupakan salah satu metode Data Mining yang dapat menggambarkan tingkat akurasi yang baik dan cukup tinggi dalam klasifikasi sebuah penyakit ginjal Kronis. Dalam klasifikasi penyakit ini dapat dilihat klasifikasi terhadap dataset diagnosoa penyakit ginjla kronis. Data yang dihasilkan dari penerapan terhadap klasifikasi diagnose penyakit ginjal kronis ini dapat diterapkan menggunakan sistem komputerisasi, karena dalam penggunaan metode Naïve Bayes ini sangat banyak jenis aplikasi yang dapat diterapkan[7].

\section{METODOLOGI PENELITIAN}

\subsection{Metodologi Penelitian}

Penelitian ini menggunaka metode kuantitatif yang bersifat sistematis dan matematis dan dilakukan beberapa tahapan metodologi dalam pengambilan data pada umumnya berupa[8]:

1. Observasi

Berupa aktivitas untuk mengetahui tentag penyakit ginjal kronis terhadap dokter yang bersangkutan,, dan mengenali dan menggali informasi-informasi yang terkait.

2. Wawancara

Wawancara terhadap penderita penyakit ginjal kronis akan gejala dan hal-hal yang berkaitan dengan penyakit ginjal kronis. Dengan membuat pertanyaan tertentu dan melakukan pengambilan data secara Tulisan maupun rekaman suara dan video.

3. Studi Pustaka

Mencari dari beberapa narasumber terpecaya dari jurnal kesehatan dan teknologi yang terakreditasi yang dapat diakses melalui internet, Buku-buku ilmiah.

Metodologi penelitian selanjutnya dapat digambarkan beberapa tahapannya pada gambar 1[7].

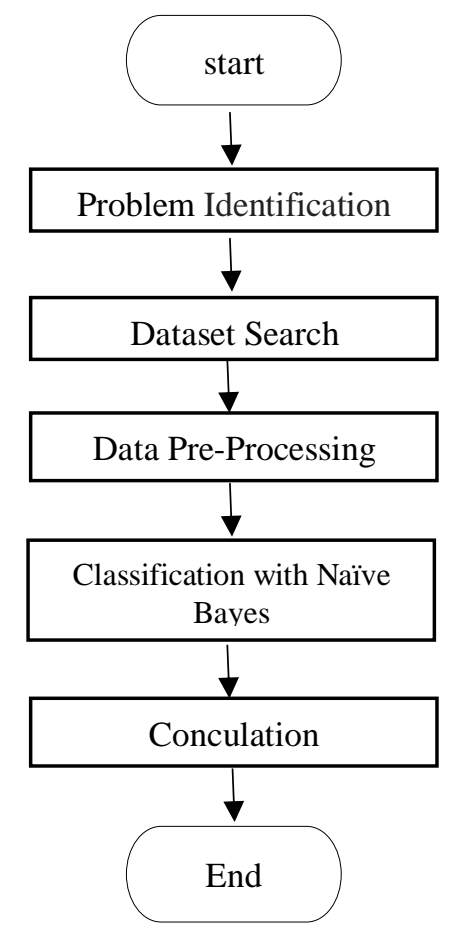

Gambar 1. Metodologi Penelitan Dengan Naïve Bayes 


\subsection{Naïve Bayes Classifier}

Naïve Bayes classifier adalah salah satu algoritma yang mengambil bagian dari ilmu statistika yaitu teori kemungkinan atau sering disebut dengan Probabilitas dan merupakan salah satu algoritma data mining metode klasifikasi untuk menyelesaikan kasus himpuan data pada kelas atau tabel sebagai acuan target yang akan ingin diketahui, naïve bayes juga merupakan metode yang berakar pada teorema bayes dan ciri khas yang paling utama dari Naïve Bayes ini adalah penekanan yang kuat terhadap independensi dari setiap kondisi atau setiap kejadian, teori bayes itu sendiri berasal dari kebiasaan dari memakai rumus bayes untuk mencari praduga dari proses suatu kesimpulan[9].

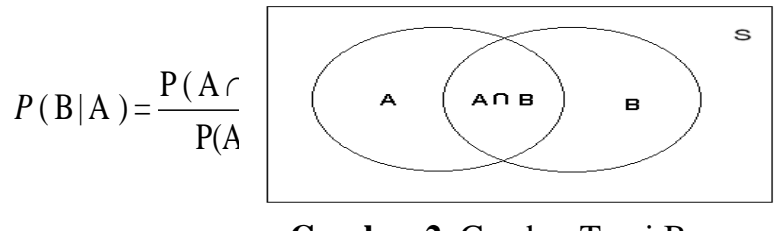

Gambar 2. Gambar Teori Bayes

Proses/fase dalam klasifikasi untuk menghasilkan sebuah keputusan yang akurat

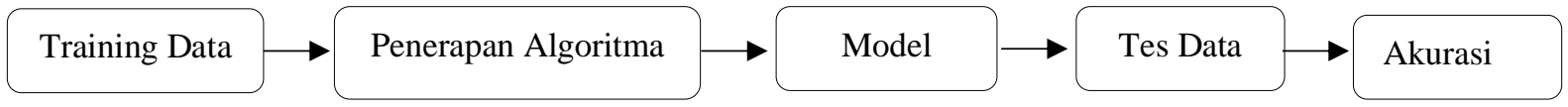

Gambar 3. Fase Metode Klasifikasi dalam Tahapan Penyelesaian Masalah

\section{HASIL DAN PEMBAHASAN}

Dalam penelitian harus dilakukan identifikasi terhadap gejala-gejala penyakit ginjal kronis, dan penyakit yang memiliki kemiripan terhadapt bebrapa gejala, data pada table 1[10]. menunjan gejala-gejala yng merupakan indikasi dari penyakit Bagian daerah perut dimana ginjal terletak, biasanya sering terjadi kesalahan terhadap diagnosa penyakit didaerah perut terutama ginjal yang biasa dianggap penyakit "masuk angin" oleh masyarakat Indonesia, jika sebuah penyakit dianggap sama dan terus dibiarkan tanpa ada deteksi dini yang akan terjadi selanjutnya dapat mempertambah resiko terhadap diri, maka dari itu perlu diketahui dan ditandai dengan pasti terhadap penyakit yang sedang dirasakan oleh tubuh. Berikut ini merupakan diagnosa penyakit mengunakan pendekatan algoritma Naïve Bayes[11]:

Tabel 1. Gejala Penykit Ginjal[4].

\begin{tabular}{llcccc}
\hline NO & \multicolumn{1}{c}{ GEJALA } & $\begin{array}{c}\text { Infeksi } \\
\text { Saluran } \\
\text { Kemih }\end{array}$ & $\begin{array}{c}\text { Ginjal } \\
\text { tahapan } \\
\text { awal }\end{array}$ & $\begin{array}{c}\text { Ginjal } \\
\text { Kronis }\end{array}$ & $\begin{array}{c}\text { Tukak } \\
\text { Lambung }\end{array}$ \\
\hline 1 & Berat Badan Menurun & Tidak & Ya & Ya & ya \\
2 & Volume Air Kencing Berkurang & Tidak & Ya & Tidak & Tidak \\
3 & Kejang-Kejang & Tidak & Tidak & Tidak & Tidak \\
4 & Demam & Tidak & Tidak & Ya & Tidak \\
5 & Muntah & Tidak & Tidak & Ya & Ya \\
6 & Diare & Ya & Tidak & Ya & Ya \\
7 & Mudah Lelah & Tidak & Tidak & Ya & Tidak \\
8 & Penyakit Kulit ruam/kering & Tidak & Tidak & Tidak & Tidak \\
9 & Bengkak Pada Bagian Tubuh & Ya & Ya & Ya & Tidak \\
10 & Sesak Nafas & Tidak & Tidak & Ya & Tidak \\
11 & Sulit Bekerja Keras & Ya & Tidak & Ya & Ya \\
12 & Hidung Berdarah & Tidak & Tidak & Tidak & Tidak \\
13 & Cegukan Yang Terlalu Sering & Tidak & Tidak & Tidak & Tidak \\
14 & Penurunan Kesadaraan & Ya & Tidak & Ya & Ya \\
15 & Pengelihatan Kabur & Tidak & Tidak & Tidak & Tidak \\
16 & Lemas & Ya & Tidak & Ya & Tidak \\
17 & Darah Dari Air Kencing & Tidak & Tidak & Tidak & Tidak \\
18 & Nyeri Perut Daerah Ginjal & Tidak & Tidak & Tidak & Tidak \\
19 & Nyeri Punggung & Tidak & Tidak & Tidak & Tidak \\
20 & Lamanya Luka Sembuh & Tidak & Tidak & Tidak & Tidak \\
21 & Terlalu Sering Buang Air Kecil Tetapi Sedikit & Tidak & Tidak & Tidak & Tidak \\
22 & Nafsu Makan Menurun & Ya & Ya & Ya & ya \\
23 & Mengigil Kedinginan & Ya & Ya & Tidak & Tidak \\
24 & Sakit Ketika Makan & Tidak & Tidak & Tidak & Tidak \\
\hline & & & &
\end{tabular}


JURNAL MEDIA INFORMATIKA BUDIDARMA

Volume 4, Nomor 3, Juli 2020, Page 850-854

ISSN 2614-5278 (media cetak), ISSN 2548-8368 (media online)

Available Online at https://ejurnal.stmik-budidarma.ac.id/index.php/mib

DOI 10.30865/mib.v4i3.2292

\begin{tabular}{llllll}
\hline 25 & Mudah Mengantuk & Tidak & Tidak & Tidak & Tidak \\
\hline
\end{tabular}

\subsection{Tahapan Penyelesaian Naïve Bayes}

Dalam penelitian ini tedapat beberapa sampel ppenderita yang mengarah penyakit Ginjala Kronis dengan tandatanda fisik yang tertera pada table berikut

Tabel 2. data Diagnosa Penyakit Ginjal Kronis

\begin{tabular}{|c|c|c|c|c|c|c|c|c|}
\hline No & Nama & $\begin{array}{l}\text { BERAT } \\
\text { BADAN }\end{array}$ & $\begin{array}{l}\text { Sering } \\
\text { buang air } \\
\text { dengan } \\
\text { volume } \\
\text { sedikit }\end{array}$ & $\begin{array}{l}\text { Timbul } \\
\text { Penyakit } \\
\text { kulit ruam } \\
\text { dan kering }\end{array}$ & Demam & $\begin{array}{l}\text { Mual } \\
\text { dan } \\
\text { Muntah }\end{array}$ & $\begin{array}{l}\text { Hilang } \\
\text { Kesadaran }\end{array}$ & $\begin{array}{l}\text { Hasil } \\
\text { Diagnosa }\end{array}$ \\
\hline 1 & Imam & $\begin{array}{l}\text { Sangat } \\
\text { menurun }\end{array}$ & Tinggi & Banyak & $\mathrm{Ya}$ & $\mathrm{Ya}$ & $\mathrm{Ya}$ & $\mathrm{Ya}$ \\
\hline 2 & Luthfi & Stabil & Rendah & Tidak ada & $\mathrm{Ya}$ & Tidak & Tidak & Tidak \\
\hline 3 & Faisal & Stabil & Tinggi & Banyak & Tidak & $\mathrm{Ya}$ & $\mathrm{Ya}$ & $\mathrm{Ya}$ \\
\hline 4 & Iqbal & $\begin{array}{l}\text { Sangat } \\
\text { menurun }\end{array}$ & Tinggi & Tidak ada & Tidak & Tidak & Tidak & Tidak \\
\hline 5 & Kurniawan & $\begin{array}{l}\text { Sangat } \\
\text { menurun }\end{array}$ & Tinggi & Banyak & $\mathrm{Ya}$ & Tidak & $\mathrm{Ya}$ & $\mathrm{Ya}$ \\
\hline 6 & Ahmad & Stabil & Rendah & Banyak & $\mathrm{Ya}$ & $\mathrm{Ya}$ & $\mathrm{Ya}$ & $\mathrm{Ya}$ \\
\hline
\end{tabular}

Tabel 3. data Baru terahadp Diagnosa Penyakit ginjal Kronis

\begin{tabular}{llllllll}
\hline No & Nama & BERAT & $\begin{array}{l}\text { Sering } \\
\text { buang air } \\
\text { dengan } \\
\text { volume } \\
\text { sedikit }\end{array}$ & $\begin{array}{l}\text { Timbul } \\
\text { Penyakit } \\
\text { kulit ruam } \\
\text { dan kering }\end{array}$ & Demam & Diare & $\begin{array}{l}\text { Hilang } \\
\text { Kesadaran }\end{array}$ \\
\hline 1 & Richard & $\begin{array}{l}\text { Sangat } \\
\text { menurun }\end{array}$ & Rendah & Banyak & Ya & Tudak & Ya \\
\hline
\end{tabular}

Penyelesaian menggunakan pendekatan Algoritma Naïve Bayes Classifier sebagai berikut[12].

1. Hitung nilai $\mathrm{P}(\mathrm{XK} \mid \mathrm{C})$ untuk setiap class

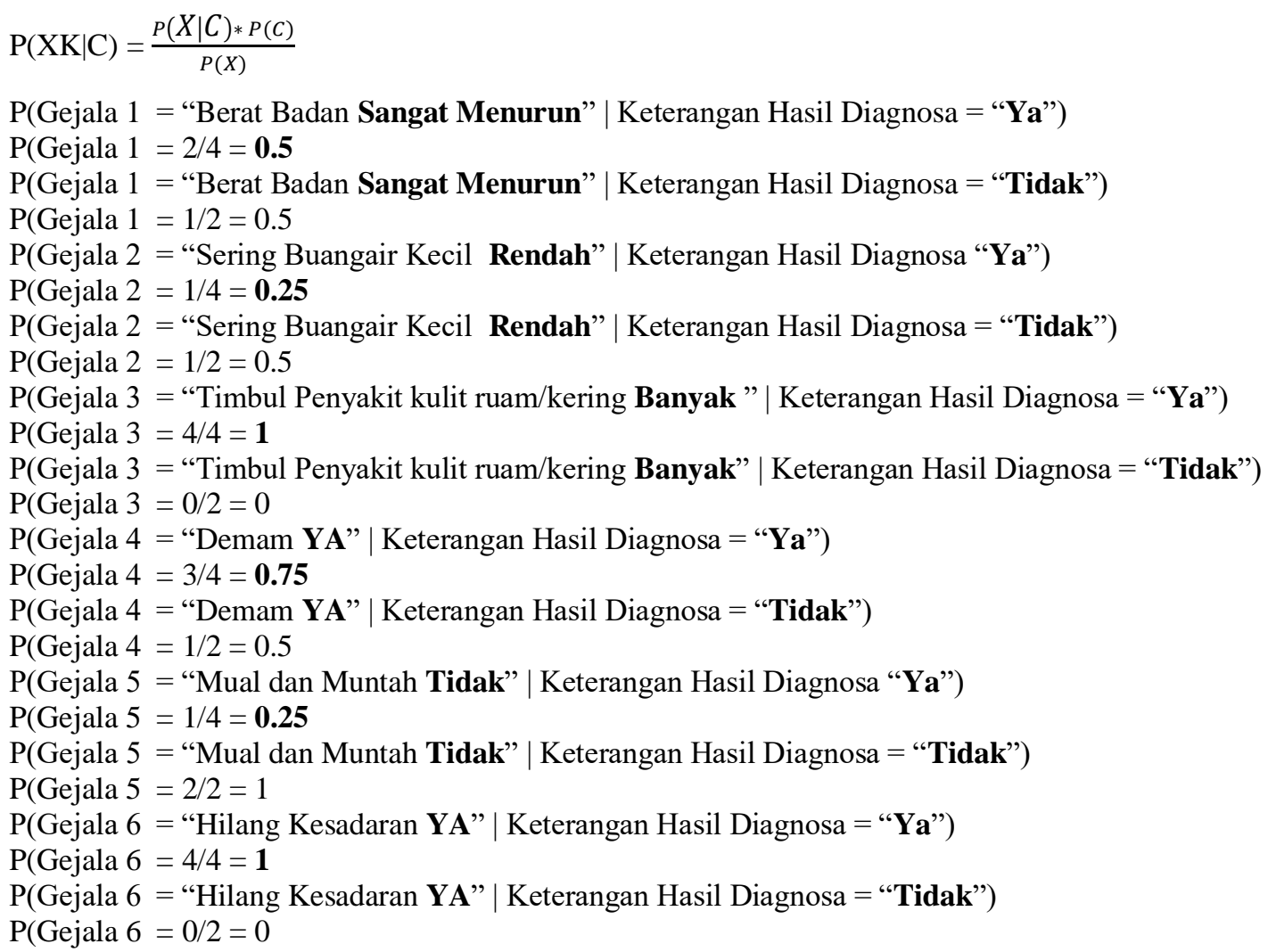

2. Hitung nilai $\mathrm{P}(\mathrm{X} \mid \mathrm{C})$ untuk setiap Kelas (label)

$\mathrm{P}(\mathrm{X} \mid$ Keterangan $=$ "Ya")

$=0,5 \times 0,25 \times 1 \times 0,75 \times 0,25 \times 1=0,023438$ 
ISSN 2614-5278 (media cetak), ISSN 2548-8368 (media online)

Available Online at https://ejurnal.stmik-budidarma.ac.id/index.php/mib

DOI 10.30865/mib.v4i3.2292

$$
\begin{aligned}
& \mathrm{P}(\mathrm{X} \mid \text { Keterangan }=\text { "Tidak" }) \\
& =0,5 \times 0,5 \times 0 \times 0,5 \times 1 \times 0
\end{aligned}
$$

3. Hitung nilai $\mathrm{P}(\mathrm{X} \mid \mathrm{C}) * \mathrm{P}(\mathrm{C})$

$(\mathrm{P}(\mathrm{X} \mid$ Keterangan $=$ "Ya") $\mathrm{x} \mathrm{P}($ Keterangan=Ya")

$=0 \times 2 / 6=0,015625$

$-(\mathrm{P}(\mathrm{X} \mid$ Keterangan $=$ "Tidak") $\mathrm{x} \mathrm{P}($ Keterangan=Tidak" $)$

4. Hasil

Berdasarkan perhitungan diatas didapatkan kesimpulan diagnose terhadap penyakit ginjal kronis berdasarkan pendekatan dan klasifikasi tiap atribut yang menunjukan Richard terdiagnosa penyaki

Tabel 4. data Baru terahadp Diagnosa Penyakit ginjal Kronis

\begin{tabular}{lllllllll}
\hline No & Nama & BERAT & $\begin{array}{l}\text { Sering } \\
\text { buang air } \\
\text { dengan } \\
\text { volume } \\
\text { sedikit }\end{array}$ & $\begin{array}{l}\text { Timbul } \\
\text { Penyakit } \\
\text { kulit ruam } \\
\text { dan kering }\end{array}$ & Demam & Diare & Hilang & $\begin{array}{l}\text { Hasil } \\
\text { Kesadaran }\end{array}$ \\
\hline 1 & Richard & $\begin{array}{l}\text { Sangat } \\
\text { menurun }\end{array}$ & Rendah & Banyak & Ya & Tudak & Ya & YA \\
\hline
\end{tabular}

\section{KESIMPULAN}

1. Dalam penerapan metode Naïve Bayes untuk diagnosa penyakit Ginjal Kronik tampak tahapan sangat mudah dalam pengambilan keputusan, dan banyak penelitian yang sudah menggunakan metode naïve bayes dikarenakan memiliki tingkat akurasi yang cukup tinggi dalam penyelesaian beberapa masalah.

2. Penggunaan Naïve Bayes dapat diterapkan dalam sistem komputer baik dalam pembentukan program baru maupun menggunakan aplikasi agar dalam pencarian data yang sangat banyak dapat dimuat dan mendapatkan hasil dengan cepat sehingga mengurangi resiko dalam perhitungan menggunakan algoritma Naïve Bayes

\section{REFERENCES}

[1] N. Rofiqo, A. P. Windarto, and D. Hartama, "Penerapan Clustering Pada Penduduk Yang Mempunyai Keluhan Kesehatan Dengan Datamining K-Means," KOMIK (Konferensi Nas. Teknol. Inf. dan Komputer), vol. 2, no. 1, pp. 216-223, 2018, doi: 10.30865/komik.v2i1.929.

[2] K. Timur, K. Utara, S. Selatan, and I. K. Sehat, "DISPARITAS PEMBANGUNAN KESEHATAN DI INDONESIA BERDASARKAN Disparity of Health Development in Indonesia Based on Healthy Family,” pp. 18-27, 2020.

[3] M. Amurwaningsih and U. Arum Darjono, "Analisis Hubungan Kualitas Hidup Yang Berhubungan Dengan Kesehatan Mulut (OHRQoL) Dan Status Kecemasan Dengan Status Nutrisi Pada Masyarakat Usia Lanjut,” Maj. Ilm. Sultan Agung, vol. 48, no. 123, pp. 46-54, 2010.

[4] E. A. Kurnianto, I. Cholissodin, and E. Santoso, "Klasifikasi Penderita Penyakit Ginjal Kronis Menggunakan Algoritme Support Vector Machine (SVM)," J. Pengemb. Teknol. Inf. dan Ilmu Komput. Univ. Brawijaya, vol. 2, no. 12, pp. 65976602, 2018.

[5] M. G. Sadewo, A. P. Windarto, and A. Wanto, "Penerapan Algoritma Clustering Dalam Mengelompokkan Banyaknya Desa/Kelurahan Menurut Upaya Antisipasi/ Mitigasi Bencana Alam Menurut Provinsi Dengan K-Means," KOMIK (Konferensi Nas. Teknol. Inf. dan Komputer), vol. 2, no. 1, pp. 311-319, 2018, doi: 10.30865/komik.v2i1.943.

[6] R. A. Saputra, "Komparasi Algoritma Klasifikasi Data Mining Untuk Memprediksi Penyakit Tuberculosis ( Tb ): Studi Kasus Puskesmas Karawang,” Semin. Nas. Inov. dan Tren, no. April, pp. 1-8, 2014.

[7] D. P. Utomo, "Analisis Komparasi Metode Klasifikasi Data Mining dan Reduksi Atribut Pada Data Set Penyakit Jantung," vol. 4, no. April, pp. 437-444, 2020, doi: 10.30865/mib.v4i2.2080.

[8] A. Nugroho, Analisis dan Perancangan Sistem Informasi dengan Metodologi Berorientasi Objek, Edisi Revi. Bandung: Informatika Bandung, 2005.

[9] N. D. Prayoga, N. Hidayat, and R. K. Dewi, "Sistem Diagnosis Penyakit Hati Menggunakan Metode Naïve Bayes," J. Pengemb. Teknol. Inf. dan Ilmu Komput., vol. 2, no. 8, pp. 2666-2671, 2018.

[10] H. Amalia, "Perbandingan Metode Data Mining Svm Dan Nn Untuk Klasifikasi Penyakit Ginjal Kronis," J. Pilar Nusa Mandiri, vol. 14, no. 1, pp. 1-6, 2018, doi: https://doi.org/10.33480/pilar.v14i1.80.

[11] A. Sulistyohati, T. Hidayat, K. Kunci: Ginjal, S. Pakar, and M. Dempster-Shafer, "Aplikasi Sistem Pakar Diagnosa Penyakit Ginjal Dengan Metode Dempster-Shafer,” Semin. Nas. Apl. Teknol. Inf., vol. 2008, no. Snati, pp. 1907-5022, 2008.

[12] D. Evanko, "Optical imaging of the native brain," Nat. Methods, vol. 7, no. 1, p. 34, 2010, doi: 10.1038/nmeth.f.284. 